\title{
How much cattle can brazil pastures support? An analysis based on "YIELD GAP"
}

\begin{abstract}
The degradation of pastures is one of Brazil's biggest problems today and directly affects the sustainability of livestock. The animal production in a degraded pasture can be six times smaller than a grazing or recovered in good maintenance state. So we can consider that productivity could be increased in pasture areas, and analyze how productivity is limited by biophysical factors (climate, for example) versus management. Using spatial datasets, we compare yield patterns for the pasturelands within regions of similar climate. We use this comparison to evaluate the potential yield obtainable for pasturelands in different climates around the Brazil using the limits of Brazilian biomes. We then compare the actual yields currently being achieved with their 'potential yield' to estimate the 'yield gap', present spatial datasets of both the potential yields and yield gap patterns for pasturelands around the year 1995 and 2006. This study is intended to be an important new resource for scientists and policymakers alike, helping to more accurately understand spatial variation of yield and agricultural intensification potential, as well as employing these data to better utilize existing infrastructure and optimize the distribution of development and aid capital.
\end{abstract}

Keywords: Yield Gap; Pastureland; Land Use; Brazilian Biomes; Stocking Rate.

\section{Quanto gado pode suportar as pastagens brasileiras? Uma análise baseada no "GAP YIELD"}

\begin{abstract}
A degradação das pastagens é hoje um dos maiores problemas do Brasil e afeta diretamente a sustentabilidade da pecuária. A produção animal em uma pastagem degradada pode ser seis vezes menor que uma pastagem ou recuperada em bom estado de manutenção. Assim, podemos considerar que a produtividade pode ser aumentada em áreas de pastagens e analisar como a produtividade é limitada por fatores biofísicos (clima, por exemplo) versus gerenciamento. Usando conjuntos de dados espaciais, comparamos padrões de rendimento para as pastagens dentro de regiões de clima similar. Utilizamos essa comparação para avaliar o rendimento potencial obtido para pastagens em diferentes climas em todo o Brasil, utilizando os limites dos biomas brasileiros. Em seguida, comparamos os rendimentos reais atualmente sendo alcançados com seu "rendimento potencial" para estimar o "intervalo de rendimento", apresentar conjuntos de dados espaciais de ambos os rendimentos potenciais e padrões de intervalo de rendimento para pastagens em torno de 1995 e 2006 . Este estudo pretende ser um novo recurso importante para cientistas e formuladores de políticas, ajudando a entender com mais precisão a variação espacial do rendimento e o potencial de intensificação agrícola, bem como empregando esses dados para melhor utilizar a infraestrutura existente e otimizar a distribuição do desenvolvimento e do capital de ajuda.
\end{abstract}

Palavras-Chave: Diferencial de Produção; Pastagens, uso do Solo; Biomas Brasileiros; Taxa de Lotação.

Topic: Desenvolvimento, Sustentabilidade e Meio Ambiente

Reviewed anonymously in the process of blind peer.

Christiane Cavalcante Leite

Instituto Federal de Alagoas, Brasil

http://lattes.cnpq.br/3119997635801028

ccleite@gmail.com

Britaldo Silveira Soares Filho

Universidade Federal de Minas Gerais, Brasil

http://lattes.cnpq.br/0835550051061850

britaldossf@gmail.com

Marcos Heil Costa

Universidade Federal de Viçosa, Brasil http://lattes.cnpq.br/8463458737785676

mhcosta@ufv.br

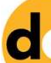

DOI: 10.6008/SPC2179-6858.2017.004.0014
Received: 15/07/2017

Approved: 16/10/2017

Ranieri Carlos Ferreira de Amorim

Centro Universitário Mauricio de Nassau, Brasi

http://lattes.cnpq.br/6639209700174709

rcfamorim@gmail.com

\section{Referencing this:}

LEITE, C. C.; SOARES FILHO, B. S.; COSTA, M. H.; AMORIM, R. C. F.. How much cattle can brazil pastures support? An analysis based on "YIELD GAP". Revista Ibero-Americana de Ciências Ambientais, v.8, n.4, p.162-169, 2017. DOI: http://doi.org/10.6008/SPC21796858.2017.004.0014 


\section{INTRODUTION}

Livestock Brazilian cut is characterized by extensive exploitation of pastures, with low productivity rates compared to meat exporting countries. However, Brazil has the largest commercial cattle herd in the world, with around 212 million head $(F A O, 2013)$, of which $88 \%$ of the beef produced in the country originates from cattle raised on pastures (ESTANISLAUS et al., 2000). For this performance occurred Brazilian cattle has used natural resources. However, this production does not occur in a harmonious way the environment can result in the destruction of natural ecosystems (the expansion of the agricultural frontier), soil degradation (which can cause compaction and erosion) and also the pollution of water resources (ZEN et al., 2008 ).

These effects may be more severe depending on the specificity of biomass production systems in which they are located. Livestock is considered one of the main causes of degradation of the Caatinga biome. This biome suffered severe changes with replacement of native plants for pasture for cattle. Between 1996 and 2006, Valente et al. (2013) using data from the Agricultural Census estimated an increase of $102.42 \%$ in cattle sold and slaughtered and increased of natural and planted pastureland areas at the expense forest areas in the Amazon biome and IBGE (Brazilian Institute of Geography and Statistics), using bovine effective data at municipal level for 2011, showed that livestock in the Cerrado biome is responsible for $34.33 \%$ of the national herd, the largest cattle herd in the country.

Therefore, the pastures are the most economical and practical way of feeding cattle and shall be duly entered on the production system as one of the principal factors. But a production system is much more complex and dynamic. There are many factors as part of the system that interact with each other, such as soil, plant, climate, animals, and man himself (ZANINE, 2005). Pasture degradation is a major problem in livestock Brazilian court, being developed mainly to pasture, directly affecting the sustainability of the production system (KICHEL et al., 2000). There is therefore the need to prevent degradation of pastures and also enhance their productivity in order to make ranching more profitable cutting and more competitive with other alternative land use, especially in the reclaimed land (CORRÊA et al., 2000).

In Brazil, the evolution of time has shown an increasing shift of natural pastureland to cultivated. Brazil has 160 million hectares of pastures, where natural pastureland are considered the main source of food for livestock in the various systems of the country. But this situation is undergoing change, where the planted pastures increased from 73,765 million hectares in 1985 to 101,437 million in 2006, an increase of $37 \%$ over 20 years. From the point of view strictly of production, it is assumed that the advancement of planted pastures on other land use, especially on natural pastures is one of the most important factors propelling the technical progress of livestock cutting and dairy (IGREJA et al., 2001).

In a previous study, Licker et al. (2010) investigated how the climate and crop management explain the yield gap of 175 cultures around the globe. In this work the same methodology will be used to study the influence of climate and agricultural management on the productivity of natural and planted pastures throughout Brazil. 


\section{METHODOLOGY}

\section{Pasture productivity}

The patterns of productivity of croplands and pasturelands are controlled by a variety of factors including climate, soil quality and human resource management (including irrigation, fertilization and crop management). Through the spatial distribution of pasture productivity data for all Brazil, it will be possible to compare the productivity of the same among climatically similar areas and investigate their drivers in a more comprehensive way.

We used data from the agricultural census municipalities level for the production of maps of pastureland planted area, stocking rate (or cattle density) and number of heads per pixel for the Brazilian biomes (see example in figure 1). The IBGE provides data of planted pasture area and number of heads for all years in the agricultural census was conducted, but in this study the analysis was focused only in 1995 and 2006. Once the agricultural census does not provide pasture productivity data for Brazil it has been calculated by dividing the number of cattle heads on pasture planted area by each municipality and was named the stocking in this study, given in head/ha. The results generated maps showing the spatial distribution of stocking pastures throughout Brazil at a spatial resolution of $5^{\prime}$ de latitude and longitude. These maps were used as the basis for statistical calculations and 50 and 90 percentiles for each biome.

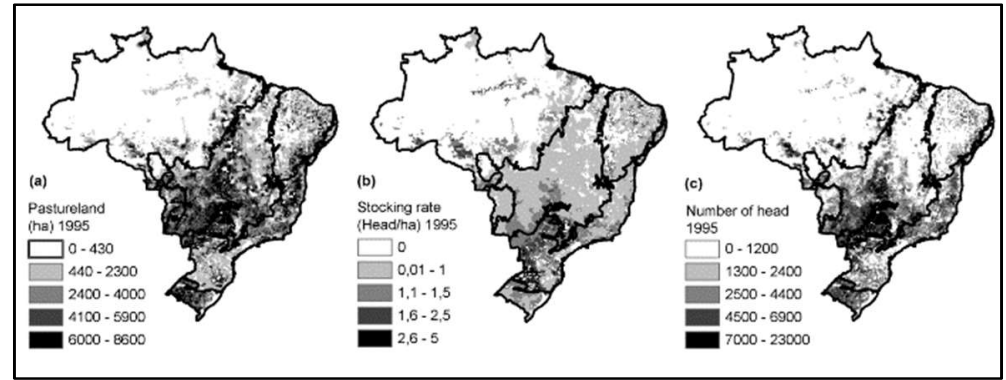

Figure 1: Maps of pastureland area per pixel (a), stocking rate (b) and number of heads per pixel (c) for Brazil in 1995 Each pixel is 5'x 5' (about $9 \times 9 \mathrm{~km}$ ).

\section{Influence of biophysical factors in stocking pastures in Brazil management}

After mapping the stocking of pastures, the analysis was focused on the key areas of livestock throughout Brazil. To filter the grid cells that are not part of the region's livestock, they were classified based on the fraction of the cell occupied by pasture. The analysis was performed on the grid cells that comprise over $95 \%$ of Brazil's area covered by pasture for livestock, the remaining $5 \%$ of the aggregate area planted (ie sparser lands) were removed from further analysis. For this analysis were used maps developed by Leite et al. (2012). These maps contain, in each cell of 5' spatial resolution, the fraction of total pasture area (natural and planted pastures) for throughout Brazil.

\section{CLIMATE}

To understand the influence of climate on the stocking of pasture was used climate classification of biomes Amazonia, Cerrado, Caatinga, Atlantic Forest, Pantanal and Pampas (Figure 2). First, were examined 
the stocking pastures data in throughout Brazil, in a spatial resolution of 5 ' $(10 \mathrm{~km} \times 10 \mathrm{~km})$. Then we were separated biomes and compared the planted pasture areas within a particular biome with stocking in that biome. This mapping biomes allowed us to analyze the effect of climate and isolate the variations of pasture stocking assigned to drivers of stocking, such as agricultural management. The analysis was made by biome, assuming that the climate on each biome is relatively uniform, ie productivity between pixels in the same biome does not depend on the climate.

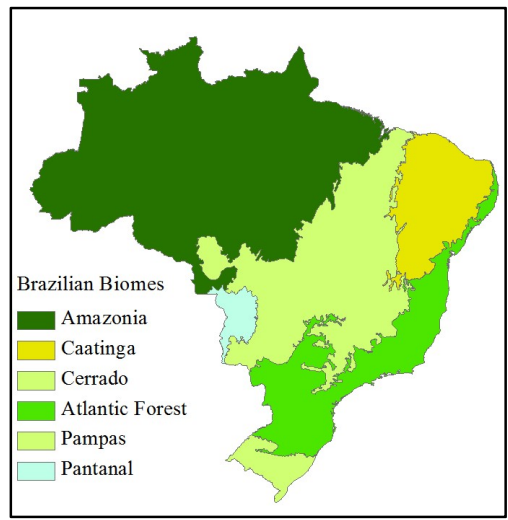

Figure 2: Study area map show the boundary of Brazilian biomes.

The pasture stocking each grid cell of 5 ' were distributed to each biome to get a pasture stocking distribution used for cattle. For each biome were generated tables containing the stocking and planted area in hectare and field position of each grid cell included in the distribution. Then were classified the data of the grid cells by their values stocking, the smaller stocking to the larger. After, starting with the grid cell with the lowest stocking were accumulated grid cells with planted pasture areas, to get statistical information mean, median, $50^{\text {th }}$ percentile and $90^{\text {th }}$ percentile of stocking. The stocking percentage value was set piling the percentage of planted area instead of the percentage of observed stocking of pasture. This avoided the pixels with small amounts of pasture skew the results.

To analyze was set the maximum values of potential stocking rate. For each biome, the value of stocking the $50^{\text {th }}$ and $90^{\text {th }}$ percentile was considered the "potential stocking". The values above the $50^{\text {th }}$ and $90^{\text {th }}$ percentile were not used to avoid incorrect or overstated values that may be included in stocking data. From this analysis, we made a mapping of patterns of potential stocking.

\section{Calculating the stocking difference in pasture (productivity deficit)}

The current stocking is stocking currently observed for each pixel from the agricultural census data. The current stocking was calculated as described in item 2.1. The current stocking can be significantly different from the potential stocking. The difference in stocking was defined by: Stocking difference $=$ Potential stocking - Current stocking; and the fraction of stocking difference is: Fraction of Stocking Difference $=1$ - (Current Stocking / Climatic Potential Stocking), where: The potential stocking is the value of the 90th percentile of the stocking; and The current stocking is the stocking observed for each pixel. 


\section{RESULTS AND DISCUSSION}

The red bars in figure 3 show the frequency distribution of the percentage of pixels for each actual value stocking rate in each biome. End, purple bars show the frequency distribution of stocking rate if the productivity of all low yield pixels were raised to the $50^{\text {th }}$ percentile, while the green bars show the same for the $90^{\text {th }}$ percentile. Most pasturelands in Amazonia (Figure 3a), Cerrado (Figure 3b), Caatinga (Figure 3c) and Pantanal (Figure 3f) have between 0.5 and 1.0 cattle heads per ha, while the Atlantic Forest (Figure 3d) and Pampa (Figure 3e) have between 1.0 and 1.5 cattle heads per ha. We also determined that the $50^{\text {th }}$ percentile of stocking rate is 0.86 heads/ha in Amazonia, 0.66 heads/ha in Cerrado, 0.67 heads/ha in Caatinga, 1.14 heads/ha in Atlantic Forest, 1.02 heads/ha in Pampa and 0.45 heads/ha in Pantanal; and the $90 \%$ percentile of stocking rate is 1.44 heads/ha in Amazonia, 1.17 heads/ha in Cerrado, 1.29 heads/ha in Caatinga, 1.95 heads/ha in Atlantic Forest, 1.21 heads/ha in Pampa and 0.63 heads/ha in Pantanal (Table 1). Using the yield gap concept (LICKER et al., 2010), we consider two hypothetical biome-wide yield increasing programs that would hypothetically increase low yield pasturelands to the $50^{\text {th }}$ percentile or to the $90^{\text {th }}$ percentile. These programs assume that the productivity is not limited by climate (assumed similar over each biome), but rather are limited by technology or management. We calculate the frequency distribution and how many cattle heads the pasturelands would have if such programs were successful.

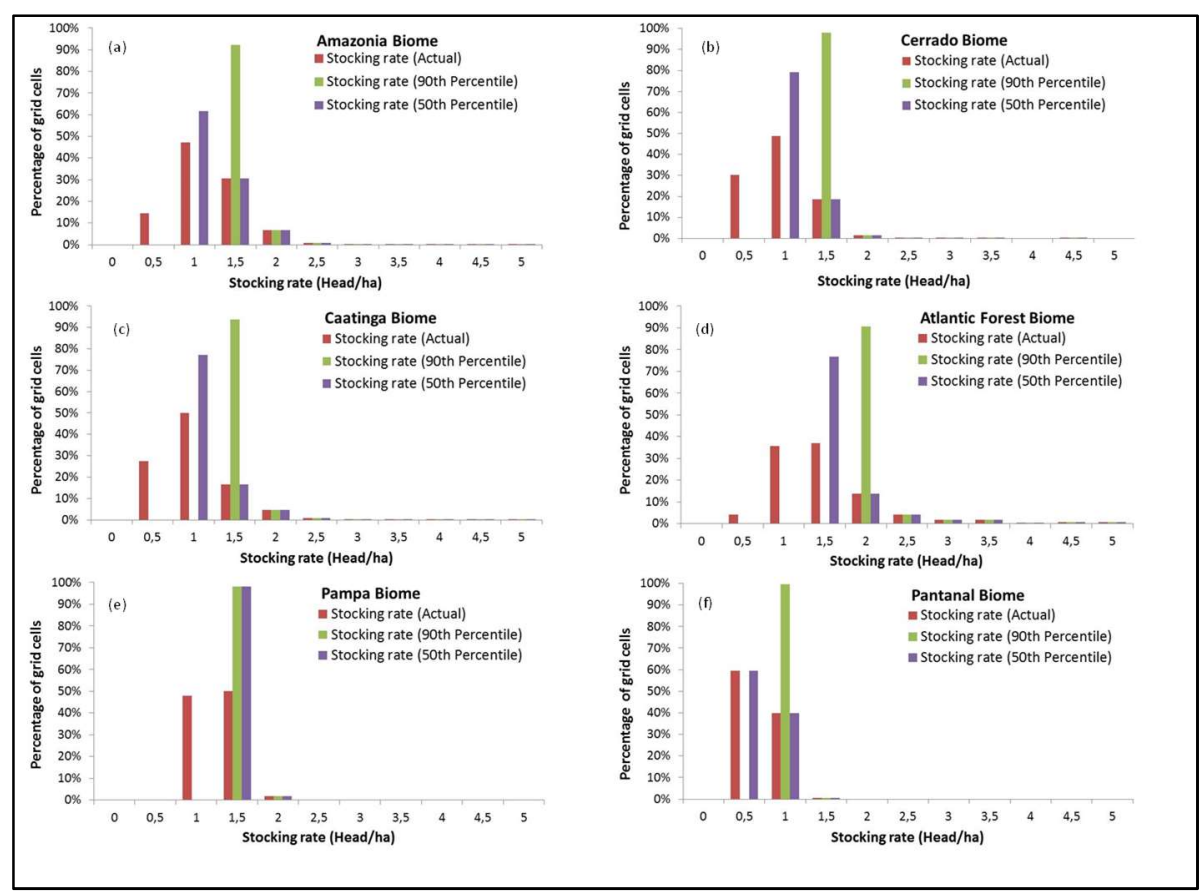

Figure 3: Histogram comparing the actual (current) stocking rate, $90^{\text {th }}$ percentile and $50^{\text {th }}$ percentile for the pasturelands in Brazilian biomes in 1995.

For 2006 (figure 4) the pasturelands in all biomes it is between 0.5 and 2.0 cattle heads per ha. Stocking rate for the $50^{\text {th }}$ percentile is 1.21 heads/ha in Amazonia (figure 4a), 0.94 heads/ha in Cerrado (figure 4b), 0.65 heads/ha in Caatinga (figure 4c), 1.37 heads/ha in Atlantic Forest (figure 4d), 1.03 heads/ha in Pampa (figure $4 \mathrm{e}$ ) and 0.48 heads/ha in Pantanal (figure $4 \mathrm{f}$ ); and the $90^{\text {th }}$ percentile of stocking rate is 1.81 heads/ha in Amazonia, 1.40 heads/ha in Cerrado, 1.90 heads/ha in Caatinga, 2.44 heads/ha in Atlantic Forest, 1.34 heads/ha in Pampa and 0.78 heads/ha in Pantanal (table 2). 


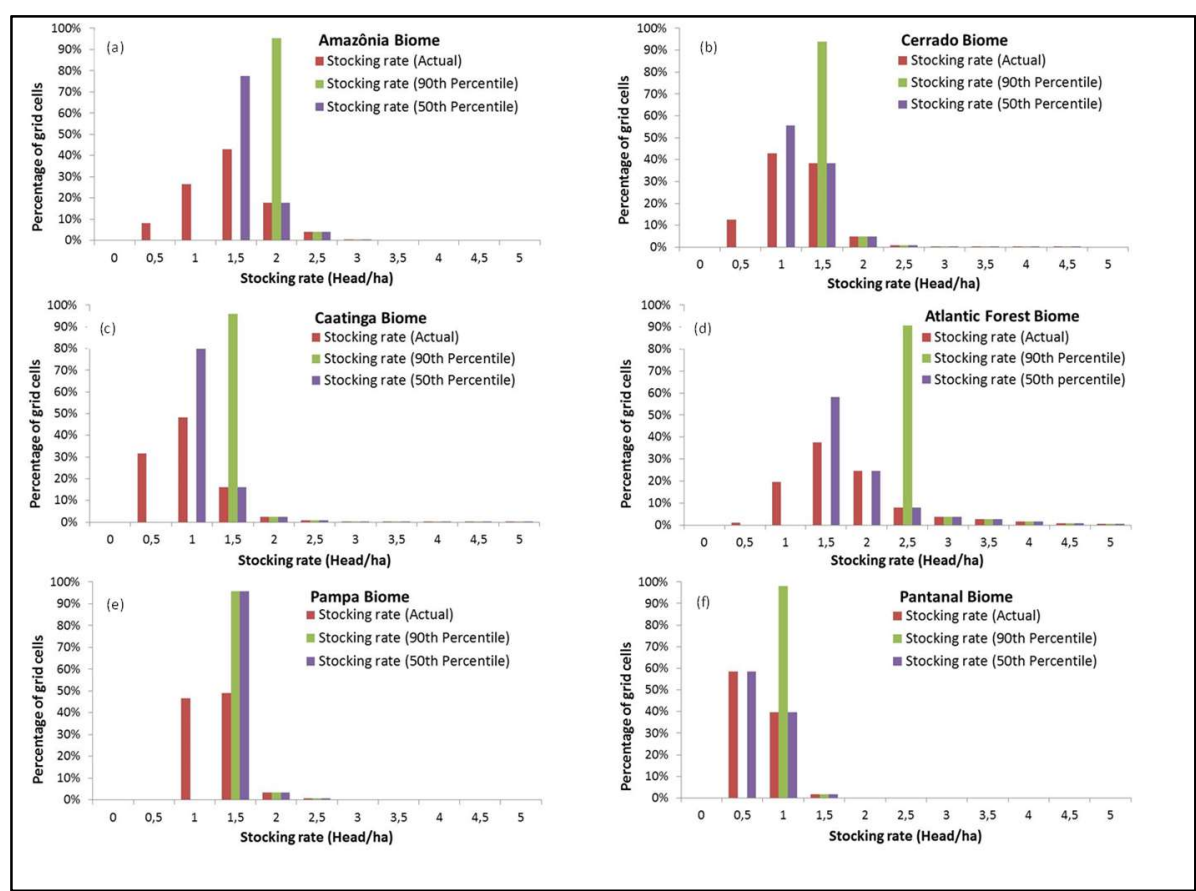

Figure 4: Histogram comparing the actual (current) stocking rate, $90^{\text {th }}$ percentile and $50^{\text {th }}$ percentile for the pasturelands in Brazilian biomes in 2006.

Finally, table 1 shows the correspondent total heads per biome for the two scenarios. We demonstrate that, using measures to raise very low productivity pasturelands to just modest yield values ( $50^{\text {th }}$ percentile), the number of heads in Amazonia could increase from 21.2 million heads to 23.9 millions, in the Cerrado from 58.2 million to 64.8 million, in the Caatinga from 12.4 million heads to 14.1 millions, in the Atlantic Forest from 47.1 million heads to 54.4 millions, in the Pampa from 8.4 million heads to 8.9 millions and in the Pantanal from 3.7 million heads to 3.8 millions. This represents a total increase of over 19 million heads $(12 \%)$ in the farms of these biomes - without increasing the pastureland area. This increase should be achievable through very modest investments in technology.

If, on the other hand, slightly higher investments in technology and management were made, and the productivity of low productivity ranches is increased to relatively high - but achievable to $10 \%$ of the pixels in each biome (the $90^{\text {th }}$ percentile scenario) - then the total number of heads would increase to 34 million in Amazonia, 91 million in the Cerrado, 23 million in the Caatinga, 82 million in the Atlantic Forest, 10 million in the Pampa and 5 million in the Pantanal. This represents a total increase of $62 \%$ over the 1995 numbers, an increase of 94 million heads just in the farms of these biomes.

Table 1: Total cattle heads possible if the stocking rate were equal to at least the $50^{\text {th }}$ percentile and at least the $90^{\text {th }}$ percentile for the Brazilian biomes in 1995.

\begin{tabular}{|c|c|c|c|c|c|c|c|c|}
\hline \multirow[b]{2}{*}{ Biomes } & \multicolumn{2}{|c|}{ Actual (1995) } & \multicolumn{3}{|c|}{ 50 ${ }^{\text {th }}$ Percentile } & \multicolumn{3}{|c|}{$90^{\text {th }}$ Percentile } \\
\hline & $\begin{array}{c}\text { Average } \\
\text { (heads/ha) }\end{array}$ & $\begin{array}{c}\text { Total heads } \\
\text { (millions) }\end{array}$ & $\begin{array}{l}\text { Minimum } \\
\text { stocking rate } \\
\text { (heads/ha) }\end{array}$ & $\begin{array}{c}\text { New average } \\
\text { (heads/ha) }\end{array}$ & $\begin{array}{c}\text { Total heads } \\
\text { (millions) }\end{array}$ & $\begin{array}{c}\text { Minimum } \\
\text { stocking rate } \\
\text { (heads/ha) }\end{array}$ & $\begin{array}{c}\text { New average } \\
\text { (heads/ha) }\end{array}$ & $\begin{array}{c}\text { Total heads } \\
\text { (millions) }\end{array}$ \\
\hline Amazonia & 0.90 & 21.258 & 0.86 & 1,05 & 23.902 & 1.44 & 1,46 & 34.028 \\
\hline Cerrado & 0.72 & 58.191 & 0.66 & 0,83 & 64.797 & 1.17 & 1,19 & 91.212 \\
\hline Caatinga & 0,78 & 12.396 & 0,67 & 0,88 & 14.116 & 1,29 & 1,34 & 22.699 \\
\hline $\begin{array}{c}\text { Atlantic } \\
\text { Forest }\end{array}$ & 1,25 & 47.147 & 1,14 & 1,42 & 54.445 & 1,95 & 2,04 & 81.888 \\
\hline Pampa & 1,03 & 8.389 & 1,02 & 1,08 & 8.907 & 1,21 & 1,23 & 10.217 \\
\hline Pantanal & 0,52 & 3.679 & 0,45 & 0,53 & 3.755 & 0,63 & 0,65 & 4.579 \\
\hline Total & - & 151.062 & - & - & 169.922 & - & - & 244.623 \\
\hline
\end{tabular}


After a decade there has been an overall increase of $12 \%$ in cattle number, this means approximately 18 million more heads in the pastures. The Table 2 shows the correspondent total heads per biome for the two scenarios using 2006 data. To $50^{\text {th }}$ percentile, the number of heads in Amazonia biome could increase from 39,7 million heads to 41,4 millions, in the Cerrado from 60,1 million to 66,6 million, in the Atlantic Forest from 45,6 million heads to 50,9 millions. This represents an increase of 13 million and 500 thousand heads just these three biomes. In the Caatinga biome the number of heads barely changed, whereas in Pampa and Pantanal quantity of cattle showed a small decrease, that when compared to 1995.

If we consider the $90^{\text {th }}$ percentile there would be an increase of $36 \%$ in the number of heads for the amazon, $44 \%$ for the Cerrado, $66 \%$ for the Caatinga, $74 \%$ for the Atlantic Forest, $32 \%$ for the pampa and 35\% for the Pantanal. This means an increase of approximately 87 million heads in relation to the actual number for this year.

Table 2: Total cattle heads possible if the stocking rate were equal to at least the 50th percentile and at least the 90 th percentile for the Brazilian biomes in 2006.

\begin{tabular}{|c|c|c|c|c|c|c|c|c|}
\hline \multirow[b]{2}{*}{ Biomes } & \multicolumn{2}{|c|}{ Actual (2006) } & \multicolumn{3}{|c|}{$50^{\text {th }}$ Percentile } & \multicolumn{3}{|c|}{$90^{\text {th }}$ Percentile } \\
\hline & $\begin{array}{c}\text { Average } \\
\text { (heads/ha) }\end{array}$ & $\begin{array}{c}\text { Total heads } \\
\text { (millions) }\end{array}$ & $\begin{array}{l}\text { Minimum } \\
\text { stocking rate } \\
\text { (heads/ha) }\end{array}$ & $\begin{array}{l}\text { New average } \\
\text { (heads/ha) }\end{array}$ & $\begin{array}{c}\text { Total heads } \\
\text { (millions) }\end{array}$ & $\begin{array}{l}\text { Minimum } \\
\text { stocking rate } \\
\text { (heads/ha) }\end{array}$ & $\begin{array}{c}\text { New average } \\
\text { (heads/ha) }\end{array}$ & $\begin{array}{c}\text { Total heads } \\
\text { (millions) }\end{array}$ \\
\hline Amazon & 1,19 & 39.697 & 1,21 & 1,38 & 41.398 & 1,81 & 1,83 & 54.112 \\
\hline Cerrado & 0,95 & 60.071 & 0,94 & 1,09 & 66.606 & 1,40 & 1,43 & 86.847 \\
\hline Caatinga & 0,74 & 12.685 & 0,65 & 0,84 & 14.056 & 1,90 & 1,24 & 21.059 \\
\hline $\begin{array}{l}\text { Atlantic } \\
\text { Forest }\end{array}$ & 1,53 & 45.605 & 1,37 & 1,70 & 50.874 & 2,44 & 2,52 & 79.522 \\
\hline Pampa & 1,06 & 6.987 & 1,03 & 1,12 & 7.488 & 1,34 & 1,36 & 9.234 \\
\hline Pantanal & 0,58 & 4.095 & 0,48 & 0,60 & 4.178 & 0,78 & 0,79 & 5.550 \\
\hline Total & - & 169.142 & - & - & 184.602 & - & - & 256.326 \\
\hline
\end{tabular}

\section{CONCLUSIONS}

Brazil has the largest commercial herd in the world. According to the data of the agricultural census 1995/1996 and 2006, the number of cattle in Brazil increased by 151.1 million to 169.1 million. In this paper, we examine the national patterns of stocking rate for 6 different biomes, estimating the differences between actual stocking rate and the climatic potential stocking rate (as defined by a comparative statistical analysis between regions with similar climatic conditions). With these estimates of the climatic stocking rate, we can effectively remove the influence of climate on stocking rate and highlight the additional rate that could be obtained through an alteration of other drivers, like pasture management.

Considering the 1995 data, if the stocking rate in the $90^{\text {th }}$ percentile is considered a potential stocking rate, ie the rate that each biome would have to reach for more yield of pastures, the number ideal heads would have to be increased by approximately $60 \%$ for the Amazon biome, $57 \%$ for the Cerrado biome, $83 \%$ for the Caatinga biome, 74\% for the Atlantic Forest biome, 22\% for the Pampa biome and 24\% for the Pantanal biome, more than the current value, whereas if the stocking rate in the $50^{\text {th }}$ percentile is considered a potential stocking rate the optimal number of heads would have to be increased by only $12 \%$ for the Amazon biome, $11 \%$ for the Cerrado biome, $14 \%$ for the Caatinga biome, $15 \%$ for the Atlantic Forest biome, $6 \%$ for the Pampa biome and $2 \%$ for the Pantanal biome, of current value. 
We can observe that the number of cattle possible if the stocking rate is at least the $90^{\text {th }}$ percentile, is considerably larger than the number of heads observed (actual), for all biomes, representing an increase of over $50 \%$, while that the number of heads possible if the stocking rate is at least the $50^{\text {th }}$ percentile showed increases that no exceeded the $17 \%$. The same goes for the 2006 data, but the numbers are smaller. If the $90^{\text {th }}$ percentile is considered the potential stocking rate the number of heads would be increased to $36 \%$ for the biome Amazon, $44 \%$ for the Cerrado biome, $66 \%$ for the Caatinga biome, $74 \%$ for the biome Mata Atlantica, 32\% the biome Pampa and 35\% for the Pantanal. However, if the $50^{\text {th }}$ percentile is considered the potential stocking rate the increase in the number of heads is not more than $12 \%$ for all biomes.

A program that focuses on raising the productivity of Brazilian pastures to reduce the productivity deficit for the minimum $50^{\text {th }}$ percentile or $90^{\text {th }}$ percentile, bring the total national cattle from 151.1 millions to 169.9 millions ( $50^{\text {th }}$ percentile) or 244.6 millions ( $90^{\text {th }}$ percentile), using 1995 data. Using data from 2006, total national cattle would be increased from 169.1 millions to 184.6 millions ( $50^{\text {th }}$ percentile) or 256.3 millions $\left(90^{\text {th }}\right.$ percentile), without further deforestation. Further advances in biotechnology, pasture management techniques and other agricultural technology may further boost maximum yields.

\section{REFERENCES}

CORRÊA, L. A.; POTT, E. B.; CORDEIRO, C. A.. Integração de pastejo e uso de silagem de capim na produção de bovinos de corte. In: SIMPÓSIO DE PRODUÇÃO DE GADO DE CORTE, 2. Anais. Viçosa: UFV, 2000.

ESTANISLAU, M. L. L.; CANÇADO JUNIOR, F. L.. Aspectos econômicos da pecuária de corte. Informe Agropecuário, v.21, n.205, p.5-16, 2000.

FAO. Food and Agriculture Organization. Several tables. Roma: FAO, 2013.

IGREJA, A. C. M.; CAMPOS, B. E. S.; BLISKA, F. M. M.. Estudo dos impactos alocativos das pastagens na Região Centro-Sul do Brasil. Agricultura em São Paulo, v.40, n.1, p.119-140, 2001.

KICHEL, A. N.; MIRANDA, C. H. B.; TAMBOSI, S. A. T.. Produção de bovinos de corte com a integração agricultura $x$ pecuária. In: SIMPÓSIO DE FORRAGICULTURA E PASTAGENS: TEMAS EM EVIDÊNCIAS. Anais. Lavras: UFLA, 2000.

LEITE, C. C. M. H.; COSTA, B. S.; SOARES-FILHO, L.; HISSA, C. B. V.. Historical land use change and associated carbono emissions in Brazil from 1940 to 1995, Global Biogeochem.
Cycles, v.26, 2011. DOI: http://doi.org/10.1029/2011GB004133

LICKER, R.; JOHNSTON, M.; FOLEY, J. A.; BARFORD, C.; KUCHARIK, C. J.; MONFREDA, C.; RAMANKUTTY, N.. Mind the gap: how do climate and agricultural management explain the 'yield gap' of croplands around the world?. Global Ecology and Biogeography, v. 19, p.769-782, 2010.

MACEDO, M. C. M.; KICHEL, A. N.; ZIMMER, A. H.. Degradação e alternativas de recuperação e renovação de pastagens. Brasília: EMBRAPA Gado de corte, 2000.

ZANINE, A. M.; SILVA, C. C.; LÍRIO, V. S.. Análise do desempenho brasileiro no mercado internacional da carne bovina. Revista Eletrônica de Veterinária, v.6, n.11, p.1-21, 2005.

ZEN, S.; BARIONI, L. G.; BONATO, D. B. B.; ALMEIDA, M. H. S. P.; RITTL, T. F.. Pecuária de corte brasileira: impactos ambientais e emissões de gases efeito estufa (GEE). In: SEMINÁRIO SOBRE PERSPECTIVAS ECONÔMICAS E TÉCNICAS DA AGROPECUÁRIA NO BRASIL. Anais. Piracicaba: CEPEA, 2008. 